\title{
Help-Wanted Advertising, Job Vacancies, and Unemployment
}

THE UPWARD DRIFT in unemployment rates after the late 1960s that culminated in double-digit unemployment in the recession of the early 1980 s has been a disappointing feature of the nation's economic performance. Most analysts see multiple causes behind that performance. One is the inflation that originated with tight labor markets in the late 1960s and accelerated with the supply shocks of the 1970s, requiring repeated doses of demand restraint that raised unemployment. But, in addition, growing structural problems, broadly defined as changes that have hampered the smooth matching of vacant jobs and unemployed workers, may have been important in the performance of this period.

In many countries, data on job vacancies are collected on as regular a basis as data on unemployment. Unfortunately for economists interested in incorporating job vacancies into their empirical analyses of the U.S. labor market, there exists no comprehensive, consistent U.S. job vacancy series. ${ }^{1}$ The best available proxy is the Conference Board's help-wanted index, which is based on help-wanted advertising in major metropolitan newspapers.

My paper has benefited from comments made by Martin Baily, Charles Brown, James Medoff, and members of the Brookings Panel on earlier drafts. I am grateful to Robert Solow for encouraging me to pursue this topic; to Kenneth Goldstein of the Conference Board and Linda Stratman of the Bureau of National Affairs for making unpublished data available to me; to Susan Allin, Kadel Mitchell, Brad Reiff, and especially Kelly Eastman for assistance with the research; and to Sara Hufham for her careful preparation of several versions of the manuscript.

1. From time to time, U.S. vacancy data have been collected for particular localities or sectors. See Katharine G. Abraham, "Structural/Frictional vs. Deficient Demand Unemployment: Some New Evidence," American Economic Review, vol. 73 (September 1983), pp. 708-24. 
Evidence of growing structural unemployment comes from the fact that the volume of help-wanted advertising associated with any given U.S. unemployment rate has increased markedly since 1970. That interpretation, however, depends on the normalized help-wanted index being a good proxy for the job vacancy rate.

The first part of this paper briefly describes how the help-wanted index is constructed and documents the marked post-1970 shift in the help-wanted-unemployment relationship. Since the appropriate interpretation of that shift depends crucially on the degree to which movements in help-wanted advertising mirror movements in the number of job vacancies, I next consider other possible sources of the increase in help-wanted advertising. Even after adjusting the help-wanted index as best I can to remove their influence, I find a substantial shift in the helpwanted-unemployment relationship. I conclude that the underlying relationship between job vacancies and unemployment has shifted.

In the third section of the paper, I turn to the question of why the shift has occurred. My discussion begins with a simple model of the relationship between vacancies and unemployment. Any of several sorts of changes could have affected the position of the equilibrium vacancyunemployment locus. The available empirical evidence is not wholly conclusive, but suggests that disparities in regional economic conditions have worsened the match between vacant jobs and unemployed workers, thus contributing to the growth in structural unemployment.

\section{The Help-Wanted-Unemployment Relationship}

The Conference Board help-wanted index is based on counts of the number of help-wanted advertisements placed in the classified sections of newspapers in fifty-one large cities. As of 1974, the metropolitan areas represented by the sample cities accounted for 49 percent of total nonagricultural employment in the continental United States. The sample and procedures used for calculating the index have remained essentially unchanged since its inception. ${ }^{2}$

2. When the help-wanted index was first constructed in 1964, fifty-two cities were selected for inclusion. Forty-five could supply data beginning with January 1951; the remaining seven supplied data beginning some time between January 1953 and January 1958. One city, Newark, New Jersey, was removed from the sample in 1971; in Hartford, Connecticut, a paper with declining circulation that later went out of business was replaced 
Only one newspaper per city, always the primary carrier of helpwanted advertising in the city, contributes to the index. Each month, the cooperating newspapers supply the Conference Board with figures on the number of help-wanted advertisements run during the month. These figures are based on the newspapers' own bookkeeping records, with data usually submitted by a clerical employee in the newspaper's advertising department. No effort is made to take account of how many jobs are listed in each advertisement; an advertisement listing fifteen full-time openings carries the same weight in the ad count as an advertisement to fill a single part-time position. The basis for the reported ad counts does differ slightly from one newspaper to another. For example, some newspapers include advertisements placed by employment agencies, while others do not. However, the reporting form used by the Conference Board requests year-ago and previous-month information in addition to current-month information, so that there is an internal consistency check on the figures supplied by each newspaper.

Once the monthly help-wanted ad count has been received from each of the cooperating newspapers, the data are adjusted to take account of differences in the number of weekdays and Sundays across months and then seasonally adjusted. Each city's standardized, seasonally adjusted ad count is normalized to a $1967=100$ base. The resulting figures are aggregated using nonagricultural payroll employment weights to create the national help-wanted index.

Figure 1 shows the upward drift of the normalized help-wanted index relative to the overall civilian unemployment rate. The vacancy-unemployment relationship, and thus the help-wanted-unemployment relationship, may be affected by the demographic composition of the labor force. But the plot of the normalized index against an unemployment rate constructed by weighting each of the unemployment rates for sixteen age-sex groups by their 1965 labor force shares looks very similar.

Table 1 reports the coefficients from models designed to capture the shifts in the relationship between the normalized help-wanted index and

with its more successful competitor, since the city's help-wanted advertising had largely switched from the one paper to the other. See Noreen L. Preston, The Help Wanted Index: Technical Description and Behavioral Trends (The Conference Board, 1977), for a more detailed description of the procedures used in calculating the help-wanted index. My discussion also draws on conversations with Kenneth Goldstein at the Conference Board. 
Figure 1. The Normalized Help-Wanted Index and Unemployment, 1951-85 ${ }^{\text {a }}$

Normalized help-wanted index

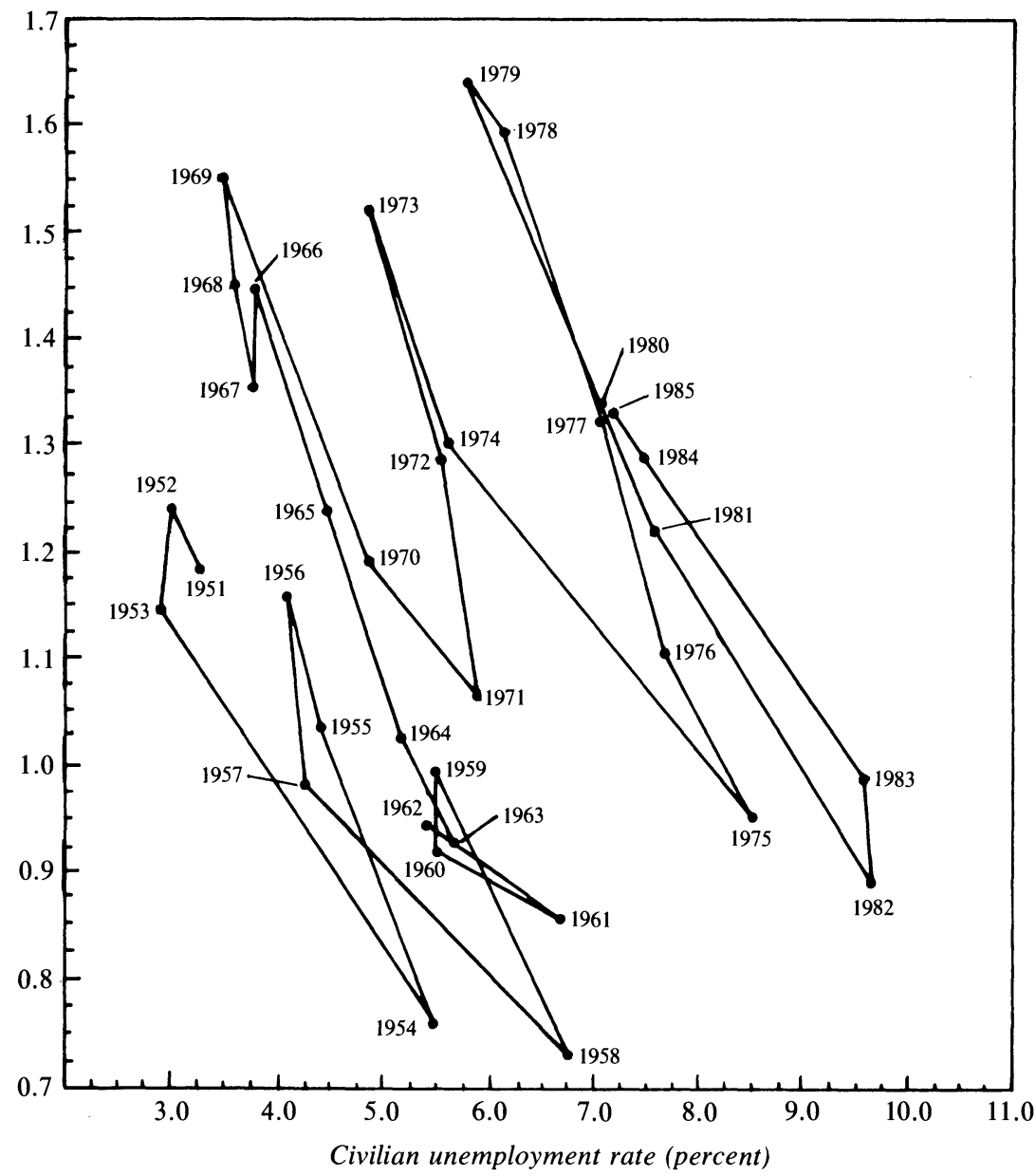

Sources: Conference Board and U.S. Department of Labor, Bureau of Labor Statistics, Handbook of Labor Statistics (Government Printing Office, June 1985) and Employment and Earnings.

a. The normalized help-wanted index equals the Conference Board help-wanted index divided by nonagricultural payroll employment in millions.

the unemployment rate, estimated using annual observations from 1960 to 1985 . The time trend coefficient in the first model implies that the help-wanted index has drifted upwards each year relative to the civilian unemployment rate by about 2.0 percent, or $(0.024 / 1.223) \times 100,1.223$ being the 1960-85 mean of the normalized help-wanted index. The post- 
Table 1. Help-Wanted Advertising and Unemployment, 1960-85

\begin{tabular}{|c|c|c|c|c|c|c|}
\hline \multirow{3}{*}{$\begin{array}{l}\text { Independent variable } \\
\text { and summary statistic }\end{array}$} & \multirow[b]{3}{*}{ Mean } & \multirow{3}{*}{$\begin{array}{l}\text { Standard } \\
\text { deviation }\end{array}$} & \multicolumn{4}{|c|}{ Dependent variable } \\
\hline & & & \multicolumn{2}{|c|}{$\begin{array}{l}\text { Normalized help- } \\
\text { wanted index }\end{array}$} & \multirow{2}{*}{$\begin{array}{c}\begin{array}{c}\text { Civilian } \\
\text { unemploy- } \\
\text { ment rate }\end{array} \\
\text { Model } 3\end{array}$} & \multirow{2}{*}{$\begin{array}{c}\text { Fixed- } \\
\text { weight } \\
\text { unem- } \\
\text { ployment } \\
\text { rate }^{\mathrm{c}}\end{array}$} \\
\hline & & & Model 1 & Model 2 & & \\
\hline Time trend & 13.50 & 7.65 & $\begin{array}{c}0.024 \\
(0.004)\end{array}$ & $\begin{array}{c}0.019 \\
(0.003)\end{array}$ & $\begin{array}{c}0.136 \\
(0.020)\end{array}$ & $\begin{array}{c}0.116 \\
(0.017)\end{array}$ \\
\hline Post-1974 shift dummy & 0.42 & 0.50 & $\begin{array}{c}0.225 \\
(0.072)\end{array}$ & $\begin{array}{c}0.200 \\
(0.061)\end{array}$ & $\begin{array}{c}1.057 \\
(0.290)\end{array}$ & $\begin{array}{c}0.841 \\
(0.243)\end{array}$ \\
\hline Civilian unemployment rate & 6.10 & 1.70 & $\begin{array}{r}-0.177 \\
(0.062)\end{array}$ & $\cdots$ & $\cdots$ & $\cdots$ \\
\hline $\begin{array}{l}\text { (Civilian unemployment } \\
\text { rate })^{2}\end{array}$ & 40.00 & 22.24 & $\begin{array}{r}-0.001 \\
(0.005)\end{array}$ & $\ldots$ & $\ldots$ & $\cdots$ \\
\hline $\begin{array}{l}\text { Fixed-weight unemploy- } \\
\text { ment rate }\end{array}$ & 5.79 & 1.55 & $\ldots$ & $\begin{array}{r}-0.215 \\
(0.059)\end{array}$ & $\ldots$ & $\ldots$ \\
\hline $\begin{array}{l}\text { (Fixed-weight unemploy- } \\
\text { ment rate })^{2}\end{array}$ & 35.84 & 19.17 & $\ldots$ & $\begin{array}{c}0.002 \\
(0.005)\end{array}$ & $\cdots$ & $\cdots$ \\
\hline $\begin{array}{l}\text { Normalized help-wanted } \\
\text { index }\end{array}$ & 1.22 & 0.23 & $\cdots$ & $\cdots$ & $\begin{array}{r}-14.880 \\
(3.618)\end{array}$ & $\begin{array}{r}-15.382 \\
(3.031)\end{array}$ \\
\hline $\begin{array}{l}\text { (Normalized help-wanted } \\
\text { index })^{2}\end{array}$ & 1.55 & 0.58 & $\ldots$ & $\cdots$ & $\begin{array}{c}4.062 \\
(1.443)\end{array}$ & $\begin{array}{c}4.179 \\
(1.208)\end{array}$ \\
\hline Constant & $\cdots$ & $\ldots$ & $\begin{array}{c}1.919 \\
(0.203)\end{array}$ & $\begin{array}{c}2.047 \\
(0.188)\end{array}$ & $\begin{array}{l}15.725 \\
(2.135)\end{array}$ & $\begin{array}{l}16.203 \\
(1.788)\end{array}$ \\
\hline \multicolumn{7}{|l|}{ Summary statistic } \\
\hline Durbin-Watson & $\ldots$ & . & 1.38 & 1.54 & 1.27 & 1.66 \\
\hline $\bar{R}^{2}$ & $\ldots$ & $\ldots$ & 0.893 & 0.920 & 0.963 & 0.969 \\
\hline
\end{tabular}

Source: Author's calculations with data from the Conference Board and U.S. Department of Labor, Bureau of Labor Statistics, Employment and Earnings, various issues.

a. Numbers in parentheses are standard errors. All models were fit using ordinary least squares (OLS).

b. Equals the Conference Board help-wanted index divided by nonagricultural payroll employment in millions.

c. Constructed by weighting the unemployment rates for each of sixteen age-sex groups by their 1965 labor force shares.

1974 dummy variable captures an additional 18 percent upward shift, for an estimated total upward shift of almost 50 percent since 1970. The coefficients in the second model imply a slightly smaller long-term drift in the help-wanted index relative to the demographically weighted unemployment rate (about 1.6 percent a year) and a slightly smaller additional upward shift after 1974 (about 16 percent), for an estimated total shift of 40 percent since 1970 . When we turn the relationship around, the coefficients in the third model imply that the civilian unemployment rate associated with any given normalized help-wanted index has risen 3.1 percentage points since 1970; the coefficients in the fourth imply that the demographically weighted unemployment rate associated with any given normalized help-wanted index has risen 2.6 percentage points over 
the same period. ${ }^{3}$ Taken at face value, the shift in the help-wantedunemployment relationship suggests that structural problems in U.S. labor markets have become increasingly serious since 1970 .

\section{Upward Drift in the Help-Wanted Index}

It is possible, however, that the help-wanted index has simply drifted upwards relative to the underlying path of job vacancies. Among the possible sources of such drift are the shift in the occupational composition of employment, and thus vacancies, away from blue-collar jobs towards more heavily advertised white-collar jobs; changes in employer advertising practices, particularly changes due to increased equal employment opportunity (EEO) and affirmative action pressures; and the decline in the number of competing newspapers in major metropolitan areas. ${ }^{4}$ One method of assessing whether help-wanted advertising does a good job of tracking vacancies is to find comparable data on both. Another is to assess the effects of other influences on the volume of help-wanted advertising.

\section{HELP-WANTED INDEX AND JOB VACANCY COMPARISONS}

Minnesota and Wisconsin are the only two states for which significant help-wanted and job vacancy data are both available. Minnesota job vacancy data were collected from 1972 through 1981. Wisconsin job

3. The table 1 equations are not structural models, but simply provide a convenient means to summarize the changing relationship between help-wanted advertising and unemployment. Various starting dates for the dummy shift variable were tried; the post1974 shift dummy outperformed dummy shift variables with other starting dates.

4. See Charlotte Boschan, "Job Openings and Help-Wanted Advertising as Measures of Cyclical Fluctuations in Unfilled Demand for Labor," in The Measurement and Interpretation of Job Vacancies (National Bureau of Economic Research, 1966), pp. 491518; Malcolm S. Cohen and Robert M. Solow, "The Behavior of Help-Wanted Advertising," Review of Economics and Statistics, vol. 49 (February 1967), pp. 108-10; John G. Myers and Daniel Creamer, Measuring Job Vacancies: A Feasibility Study in the Rochester, N.Y., Area, Studies in Business Economics 97 (The Conference Board, 1967); James Tobin, Comments on James L. Medoff and Katharine G. Abraham, "Unemployment, Unsatisfied Demand for Labor, and Compensation Growth, 1956-1980,' ' in Martin Neil Baily, ed., Workers, Jobs, and Inflation (Brookings, 1982), pp. 83-88; and Robert M. Solow, Comments on James L. Medoff, "U.S. Labor Markets: Imbalance, Wage Growth, and Productivity in the 1970s," BPEA, 1:1983, pp. 123-27. 
vacancy data cover only the years 1976 through 1981 and thus do not include the period of the early 1970s, during which the aggregate helpwanted-unemployment relationship shifted so markedly. I focus here on the Minnesota data, though the more limited Wisconsin data yield a consistent picture.

Figure 2 plots both the normalized Conference Board help-wanted index for Minnesota and the Minnesota vacancy rate from 1972 through 1981. The two series track each other quite closely except at the end of the period covered, and then the help-wanted index falls rather than rises relative to the vacancy rate. As the survey used to collect the vacancy rate data was discontinued at the end of 1981, the discrepancy may be attributable to end-of-survey problems with the vacancy series rather than to problems with the help-wanted series. The Minnesota data, then, suggest that the normalized help-wanted index is a reasonably good vacancy rate proxy. ${ }^{5}$

Among the limitations of the Minnesota data is their availability for only a ten-year period. Moreover, Minnesota differs from the rest of the country in some potentially important respects. Minorities are a smaller share of the Minnesota labor force than of the national labor force. The Minnesota labor force was 1.8 percent nonwhite in 1978; the national labor force, 12.0 percent nonwhite. EEO and affirmative action pressures on Minnesota employers may have been less intense than those on the representative U.S. employer. In addition, there have been no noteworthy changes in newspaper competition in the Minneapolis-St. Paul metropolitan area; the same two newspapers have shared that market in

5. Both help-wanted and vacancy data are also available for Canada. The Canadian help-wanted index is described in Statistics Canada, "Technical Note: The Canadian Help Wanted Index" (Ottawa: Information Canada, 1983), and the Canadian vacancy series, in Statistics Canada, Canadian Job Vacancy Survey: Technical Appendix, Catalogue 71-521 (Ottawa: Information Canada, 1972). Unfortunately, the Canadian help-wanted index is based on column inches of advertising rather than number of advertisements. Column inches of advertising may be more susceptible to changes in printing formats and advertising rates than the number of advertisements placed. In New York, Boston, and Washington, coincident with a shift in the mid-1970s at all three cities' major newspapers to a narrower column format for the help-wanted pages, with more columns per page, column inches of help-wanted advertising in those newspapers jumped upwards relative to number of advertisements. Many Canadian newspapers made similar printing format changes at about the same time. Comparison of the Canadian help-wanted and vacancy series could well give a misleading message concerning the performance of the U.S. help-wanted index as a vacancy proxy. 
Figure 2. Normalized Help-Wanted Index and Job Vacancy Rate Index, Minnesota, 1972:1-1981:4 ${ }^{\text {a }}$

Index

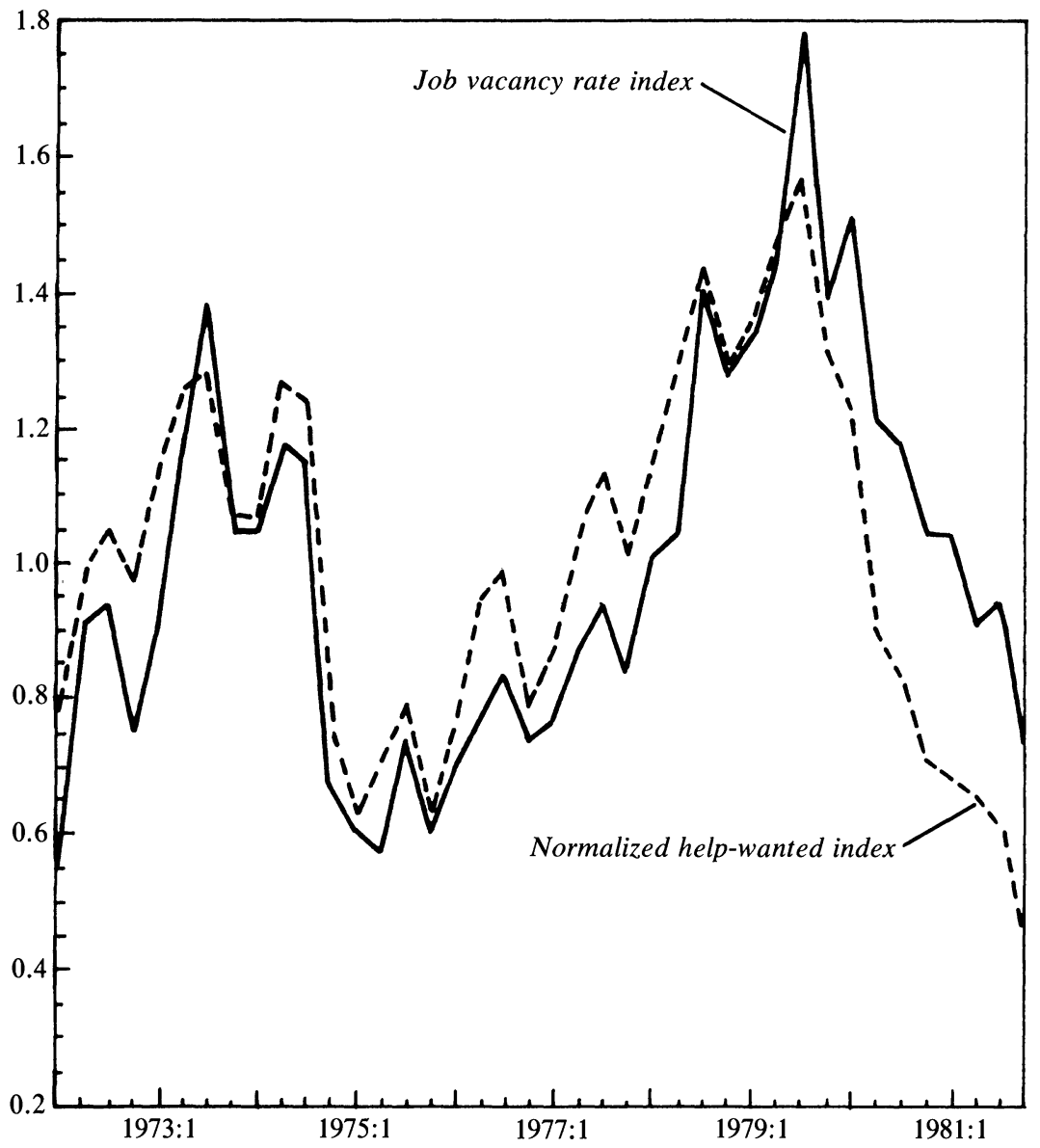

Sources: Nonseasonally-adjusted help-wanted index data for Minneapolis-St. Paul were supplied by Kenneth Goldstein of the Conference Board. Minnesota vacancy data are described in Katharine G. Abraham, "Structural/ Frictional vs. Deficient Demand Unemployment: Some New Evidence," American Economic Review, vol. 73 (September 1983), pp. 708-24.

a. The normalized help-wanted index was calculated by dividing the monthly Conference Board help-wanted index for Minneapolis-St. Paul by Minnesota nonagricultural payroll employment in millions. Both the normalized helpwanted index and the monthly job vacancy rate series were then divided by their respective sample means and converted to quarterly data. Neither series is seasonally adjusted.

essentially unchanged proportions since 1960 . Over the same time period, many other cities experienced substantial declines in newspaper competition. 
In sum, while the Minnesota data suggest that help-wanted advertising tracks vacancies quite closely, the limitations of that data are such that it seems worthwhile to consider also specific sources of upward drift that might have exerted their influence before 1972 or after 1981 or that might have affected advertising in other cities' newspapers more than advertising in the Minneapolis newspaper.

\section{SHIFTS IN THE OCCUPATIONAL COMPOSITION OF EMPLOYMENT}

An often-cited problem with the help-wanted index is that white-collar jobs are more likely to be advertised than are blue-collar jobs, so that shifts in the occupational composition of employment in recent years should have raised the volume of help-wanted advertising. Somewhat surprisingly, the available data suggest that any such upward drift has in fact been small.

Shifts in the composition of vacancies toward positions that are more likely to be advertised do cause the volume of help-wanted advertising to increase. The percentage drift in the help-wanted index attributable to such shifts over any time period from $t_{0}$ to $t_{1}$ is

$$
\text { OCCDRIFT }=\left(\frac{\sum_{i=1}^{K} R_{i} v_{i t_{1}}}{\sum_{i=1}^{K} R_{i} v_{i t_{0}}}-1\right) \times 100
$$

where the $R$ 's represent the relative probabilities that job vacancies in different occupations are advertised (here assumed to be fixed), the $v$ 's are shares of total vacancies, $i$ indexes occupations, and $t$ indexes time periods.

Data on the composition of vacancies over time are scarce, but the evidence in table 2 suggests that vacancy shares are roughly equal to employment shares across occupations, so that occupational employment shares can reasonably proxy for occupational vacancy shares. As table 2 shows, the blue-collar share of vacancies reported by firms participating in U.S. job vacancy surveys has generally been close to the blue-collar share of total employment. Canadian data also reported in table 2 reveal roughly equal vacancy shares and employment shares 
Table 2. Occupational Vacancy and Occupational Employment Shares, United States, 1965, 1966, 1979, and 1980, and Canada, 1975 ${ }^{\mathrm{a}}$

\begin{tabular}{lll}
\hline \multicolumn{1}{c}{ Country } & $\begin{array}{c}\text { Vacancy } \\
\text { share }\end{array}$ & $\begin{array}{c}\text { Employment } \\
\text { share }\end{array}$ \\
\hline United States & & \\
1965 & & \\
Non-blue-collar & 0.626 & 0.631 \\
Blue-collar & 0.374 & 0.369 \\
1966 & & \\
Non-blue-collar & 0.528 & 0.630 \\
Blue-collar & 0.472 & 0.370 \\
1979 & & \\
Non-blue-collar & 0.643 & 0.669 \\
Blue-collar & 0.357 & 0.331 \\
1980 & & \\
Non-blue-collar & 0.693 & 0.683 \\
Blue-collar & 0.307 & 0.317 \\
Canada & & \\
1975 & & \\
Non-blue-collar & & \\
Managerial-administrative & 0.057 & 0.066 \\
Professional-technical & 0.161 & 0.151 \\
Clerical & 0.171 & 0.175 \\
Sales & 0.074 & 0.111 \\
Service & 0.133 & 0.122 \\
Blue-collar & 0.405 & 0.376 \\
\hline
\end{tabular}

Sources: For the United States, vacancy shares for 1965 and 1966 are from Raymond A. Konstant and Irvin F.O. Wingeard, "Analysis and Use of Job Vacancy Statistics," Monthly Labor Review, vol. 91 (August 1968), pp. 22-31, and apply to the cities that participated in the pilot vacancy surveys conducted in April 1965 and April 1966. U.S. vacancy shares in 1979 and 1980 are from Lois Plunkert, Job Openings Pilot Program: Final Report, Bureau of Labor Statistics, Office of Employment Structure and Trends, Report BLS/EST/JB OPS (National Technical Information Service, 1981), and apply to the four states that participated in the quarterly pilot vacancy surveys conducted from March 1979 through June 1980. Employment shares for the United States are annual averages from Employment and Earnings, various issues. Vacancy shares for Canada are from Statistics Canada, Annual Report 1978 (Ottawa: Statistics Canada, 1978); employment shares are from Statistics Canada, Canada Year Book 1978-79 (Ottawa: Statistics Canada, 1978).

a. Shares (expressed as decimals) measure the ratio of vacancies and employment in each occupation to the total. Figures are rounded and therefore may not sum to 1.0 .

for more disaggregated occupational groups ${ }^{6}$ The approximate equality of occupational vacancy and employment shares may be surprising in view of what casual observation suggests are large differences in turnover rates across occupations. However, high-turnover positions tend to be

6. British data are also consistent with the notion that occupational vacancy shares are roughly equal to occupational employment shares. See Richard Jackman, Richard Layard, and Christopher Pissarides, "On Vacancies," Discussion Paper 165 (London School of Economics, Centre for Labour Economics, August 1984). 
filled more quickly than low-turnover positions. ${ }^{7}$ In steady-state equilibrium, the number of vacancies equals the flow of new vacancies times average vacancy duration. High turnover rates and short vacancy durations thus have offsetting effects on the vacancy rate, yielding roughly equal vacancy rates across occupations, which in turn implies that, for each occupation, vacancy and employment shares are roughly equal. Equation 1 can thus be rewritten

$$
\text { OCCDRIFT }=\left(\frac{\sum_{i=1}^{K} R_{i} e_{i t_{1}}}{\sum_{i=1}^{K} R_{i} e_{i t_{0}}}-1\right) \times 100,
$$

where the $e$ 's are shares of nonagricultural employment, and everything else is as before.

The relative probability of job vacancies in different occupations being advertised can be inferred from information on the occupational distribution of help-wanted advertising and on either the occupational distribution of job vacancies, or, if vacancy rates are equal across occupations, the occupational distribution of employment. One study of the Rochester, New York, labor market during the 1960s produced data on both the proportion of help-wanted advertising and the proportion of job vacancies in each of eight broad occupational categories. The implied relative probabilities that job vacancies in these occupations are advertised are reported in the first two columns of table 3. Another more recent and larger-scale study looked at the occupational distribution of help-wanted advertisements in a sample of nineteen newspapers in twelve cities. Relative advertising probabilities that assume that the occupational distribution of employment in these twelve cities matches

7. Donald O. Parsons, "Models of Labor Market Turnover: A Theoretical and Empirical Survey," in Ronald G. Ehrenberg, ed., Research in Labor Economics (JAI Press, 1977), pp. 185-223, presents evidence that managers and professionals have longer tenures, and thus presumably lower separation rates, than operatives and laborers. Data reported in Lois Plunkert, Job Openings Pilot Program: Final Report, U.S. Bureau of Labor Statistics, Office of Employment Structure and Trends, Report BLS/EST/JB OPS (National Technical Information Service, 1981), indicate that 25 percent of job openings for managers and more than 50 percent of job openings for engineers and scientists took more than a month to fill; in contrast, more than 80 percent of job openings for construction workers, transportation workers, production workers, and laborers were filled within a week. 
Table 3. Help-Wanted Advertising and the Occupational Composition of Employment

\begin{tabular}{|c|c|c|c|}
\hline \multirow[b]{3}{*}{$\begin{array}{l}\text { Occupational } \\
\text { category }\end{array}$} & \multicolumn{3}{|c|}{ Relative probability that vacancy is advertised ${ }^{\mathrm{a}}$} \\
\hline & \multicolumn{2}{|c|}{$\begin{array}{c}\text { Normalized ratio of advertisements } \\
\text { to vacancies }\end{array}$} & \multirow{2}{*}{$\begin{array}{l}\text { Normalized } \\
\text { ratio of } \\
\text { advertisements } \\
\text { to employ- } \\
\text { ment, } 1975^{\mathrm{c}} \\
\text { (3) }\end{array}$} \\
\hline & $\begin{array}{c}\text { Rochester, } \\
\text { New York, } \\
\text { February } 1965 \\
\text { (1) }\end{array}$ & $\begin{array}{l}\text { Rochester, } \\
\text { New York, } \\
\text { May } 1965 \\
\text { (2) }\end{array}$ & \\
\hline Professional-technical & 0.57 & 0.50 & 1.32 \\
\hline Managerial & 4.19 & 2.70 & 0.94 \\
\hline Clerical & 4.81 & 1.63 & 1.76 \\
\hline Sales & 7.32 & 2.59 & 4.10 \\
\hline Blue-collar & 1.00 & 1.00 & 1.00 \\
\hline Skilled & 1.41 & 1.38 & $\ldots$ \\
\hline Semiskilled & 0.69 & 0.81 & $\ldots$ \\
\hline Unskilled & 0.93 & 0.73 & $\ldots$ \\
\hline Service & 4.85 & 3.14 & 2.76 \\
\hline
\end{tabular}

Sources: Author's calculations. The data underlying the first two columns are from John G. Myers and Daniel Creamer, Measuring Job Vacancies: A Feasibility Study in the Rochester, N.Y., Area, Studies in Business Economics 97 (The Conference Board, 1967), p. 98. The help-wanted data underlying the third column are from John Walsh, Miriam Johnson, and Marged Sugarman, Help Wanted: Case Studies of Classified Ads (Salt Lake City: Olympus Publishing Co., 1975), p. 87. Data on employment by occupation are from Employment and Earnings, various issues.

a. The numbers reported equal $\left(H W I_{j} / V_{j}\right)$ divided by $\left(H W I_{B C} / V_{B C}\right)$, where $H W I_{j}$ represents occupation $j$ 's share of help-wanted advertising and $V_{j}$ represents occupation $j$ 's share of job vacancies (first two columns) or employment (third column). The normalization chosen yields estimates of the relative probability that vacancies in other occupations are advertised, compared with the probability for blue-collar vacancies. Thus, for example, the 0.57 in the upper left-hand corner means that professional-technical vacancies are 57 percent as likely to be advertised as blue-collar vacancies.

b. Normalized ratio of number of help-wanted advertisements to number of job vacancies in Rochester, New York.

c. Normalized ratio of the share of help-wanted advertisements in twelve cities (nineteen newspapers) to the national share of nonagricultural employment.

the national distribution and that the job vacancy rate is equal across occupations are reported in the third column of table 3.

The estimated relative advertising probabilities from the three available sources of data do differ noticeably. The most important figures are those for professional-technical, clerical, and blue-collar, particularly semiskilled blue-collar, positions, since these are the categories of employment whose shares have changed the most. ${ }^{8}$ All three sets of estimates support the generalization that clerical vacancies are more likely to be advertised than blue-collar vacancies, but the evidence regarding professional-technical vacancies is mixed.

8. The share of professional-technical employment in total nonagricultural employment grew 4.7 percentage points between 1960 and 1982, and that of clerical employment 3.0 percentage points. The blue-collar employment share fell 9.1 percentage points, with the largest drop among semiskilled blue-collar workers, whose share fell 5.0 percentage points. 
Estimates of the drift in the help-wanted index relative to vacancies over various subperiods based on the estimated sets of relative advertising probabilities and the changes in the employment shares of the various occupational groups appear below (numbered columns correspond to those in table 3$).{ }^{9}$

\begin{tabular}{crrr} 
& \multicolumn{3}{c}{ Implied percentage drift } \\
Period & $(1)$ & $(2)$ & $(3)$ \\
$1960-65$ & -0.8 & -1.0 & 0.0 \\
$1965-70$ & 0.8 & -0.5 & 0.0 \\
$1970-75$ & 2.8 & 2.1 & 2.3 \\
$1975-80$ & 0.6 & 0.0 & -0.4
\end{tabular}

Changes in the occupational composition of employment did not have a huge effect on the help-wanted-unemployment relationship during any subperiod, but did account for roughly a one-half percent annual drift in the help-wanted index between 1970 and 1975. ${ }^{10}$

\section{CHANGES IN ADVERTISING PRACTICES}

A second concern about using the help-wanted index as a vacancy proxy is that, either because of growing EEO and affirmative action pressures or for some other reason, employers might now be more likely to advertise any given job opening than they would have been in the past.

Affirmative action pressures have clearly had a significant effect on employers' personnel practices, including their recruiting practices. And although government officials with EEO and affirmative action responsibilities tend to be more interested in whether firms have made targeted efforts to recruit minorities and women than in whether firms advertise their job openings in general circulation newspapers, it is likely that EEO and affirmative action concerns have caused at least some increase in the volume of help-wanted advertising.

Though I have no direct evidence on the influence of EEO and affirmative action pressures, I do have information on changes in

9. The Bureau of Labor Statistics' occupational employment estimates for 1985 are not comparable to those for 1980 , so that the effect of changing occupational mix on the volume of help-wanted advertising during 1980-85 cannot be estimated.

10. These estimates are quite robust to alternative assumptions concerning relative vacancy rates in white-collar and blue-collar occupations. 
employers' advertising practices since the late 1960s. The Bureau of National Affairs (BNA) has conducted two surveys on recruiting practices, the first in 1968 and the second in 1979. ${ }^{11}$ The employee categories are not identical in the two surveys, but I assume the 1968 collegegraduate category and the 1979 managerial-professional category are comparable and that the non-college-graduate and office-production categories are also comparable. The proportion of small employers (those with fewer than 1,000 employees) reporting that they advertised college-graduate positions increased about one-fourth between the two survey dates ( 74 percent to 91 percent); the proportion of large employers (those with 1,000 or more employees) advertising college-graduate positions increased about one-half (59 percent to 91 percent). If the 1968 survey response rate was not too far out of line with BNA's usual experience, these differences between the two surveys are statistically significant at better than the 0.05 level. There was no significant change in the proportion of either small or large employers reporting that they advertised non-college-graduate positions. A crude estimate based on these figures would be that EEO and affirmative action pressures raised the volume of help-wanted advertising about 10 percent between the late 1960 s and the late 1970 s. ${ }^{12}$

My best guess about when during the roughly ten-year period between

11. For a discussion of the 1968 survey, see Bureau of National Affairs, "Recruiting Practices," Personnel Policies Forum, Survey No. 86 (Washington, D.C.: Bureau of National Affairs, Inc., March 1969). The survey panel included 226 employers; 30 percent had fewer than 1,000 employees and 70 percent had more than 1,000. BNA personnel estimate that roughly 50 percent of the survey panel responded to the survey. The data for 1979 are based on eighty-one small-employer responses and sixty-five large-employer responses to the survey described in Bureau of National Affairs, "Recruiting Policies and Practices," Personnel Policies Forum, Survey No. 126 (Washington, D.C.: Bureau of National Affairs, Inc., July 1979). Linda Stratman of the BNA gave me access to this information. For comparability with the 1968 data, not-for-profit organizations were excluded from my tabulations of the 1979 survey responses, though in fact their advertising practices were very similar to those of business firms.

12. This estimate assumes that the likelihood of a vacancy being advertised is proportional to the fraction of employers saying they use help-wanted advertisements. Within each employer size group, I gave the change-in-advertising-probability estimate for college-graduate vacancies a weight of one-third and that for non-college-graduate vacancies a weight of two-thirds; these weights correspond to the employment shares reported in Employment and Training Report of the President, 1981. In aggregating, I gave the small-employer estimate a weight of 0.75 and the large-employer estimate a weight of 0.25 ; these weights correspond to the distribution of employment in establishments with fifty or more employees reported in United States Bureau of the Census, County Business Patterns 1980 (Government Printing Office, 1983). 
the two BNA surveys the change in advertising practices occurred is that it followed the 1973 settlement of the landmark AT\&T case and the subsequent intensification of EEO and affirmative action enforcement efforts. ${ }^{13}$ A 10 percent cumulative change between 1973 and 1978 implies an average change of roughly 2 percent in each of those five years.

\section{THE DEMISE OF COMPETITION IN THE NEWSPAPER INDUSTRY}

A final concern about using the help-wanted index as a vacancy proxy is that declining competition in the newspaper industry might have caused the index to drift upwards, since as some newspapers have gone out of business, employers may have become more likely to advertise any particular job opening in the surviving papers. The number of separate newspapers in the fifty-one cities covered by the Conference Board's survey has fallen significantly, from 148 in 1960 to 87 in 1985. As their competitors have gone out of business, the weighted mean share of total circulation in those cities accounted for by newspapers reporting to the Conference Board has grown, from 60 percent in 1960 to 80 percent in $1985 .{ }^{14}$

An assessment of whether and to what extent declines in competition in the newspaper industry have caused the help-wanted index to drift upwards can be made using state data on help-wanted advertising. The newspaper competition argument implies that, ceteris paribus, the increase in the help-wanted index should have been greatest in those states where the decline in newspaper competition was greatest. The first step in assessing whether this has been the case is to identify the piece of the growth in state help-wanted indexes that cannot be linked to differences in local labor market tightness. I approximated this residual by estimating the following equation using annual observations for each of twenty-nine states from 1961 through 1985:

$$
D N H W I_{i t}=\alpha_{0}+\alpha_{1} D E M P_{i t}+\alpha_{2} D E M P_{i t-1}+\epsilon_{i t},
$$

13. See Phyllis A. Wallace, ed., Equal Employment Opportunity and the AT\&T Case (MIT Press, 1976), for a discussion of the AT\&T case's importance.

14. The annual IMS Directory of Publications (IMS Press) lists daily newspapers and their circulations. Where there was any evidence that two papers in a particular city were not in fact competing papers (same publisher, joint Sunday edition, advertising space sold together, and so forth), they were counted as a single paper. In computing circulation shares, Sunday circulations were used wherever available. The Christian Science Monitor and the various editions of the Wall Street Journal were not considered local newspapers. 
where $D N H W I$ represents the percentage change in the normalized helpwanted index, and $D E M P$ represents the percentage change in nonagricultural payroll employment. ${ }^{15}$

The second step is to test whether changes in the intensity of newspaper competition help to explain the residual growth in the helpwanted index. Table 4 reports estimates of models fit with state-specific five-year averages of the equation 3 residuals as the dependent variable. The unit of observation in these models is the state during successive five-year intervals since 1960 . The explanatory variable in the first model is the percentage change in the circulation share of newspapers in the Conference Board sample, constructed as a weighted average (using employment in each Standard Metropolitan Statistical Area as weights) of the relevant percentage changes for cities within each state. The significant positive coefficients suggest that declines in competition from other newspapers do raise the volume of advertising in the newspapers that report to the Conference Board.

The first model does not control for other influences on the vacancy rate and thus on the volume of help-wanted advertising. The second replicates the first for the 1975-80 and 1980-85 observations only, for which an appropriate set of additional control variables could be constructed. The estimated change-in-circulation-share coefficient in this restricted sample is very close to that in the full sample. Additional control variables are introduced in the third model. The rationale for including the demographic-composition-change variables is that teenagers and women may be less interested in finding new jobs when they become unemployed, and perhaps also have higher turnover rates, than adult men. The estimated coefficients provide no evidence for these hypotheses, though the percentage of the labor force aged sixteen to nineteen may be a poor proxy for the proportion of young workers loosely attached to the labor force. The rationale for including the manufacturing-share-change variable is that aggregate vacancies may be higher where there have been larger shifts in the sectoral composition of employment. The variable's estimated positive coefficient is consis-

15. Theory suggests that help-wanted advertising and unemployment should move in opposite directions over the business cycle. Unfortunately, consistent state-specific unemployment data were not available for the full time period; the percentage change in employment is the best available proxy for the change in the unemployment rate. Alternative specifications of equation 3 yielded qualitatively similar results. 


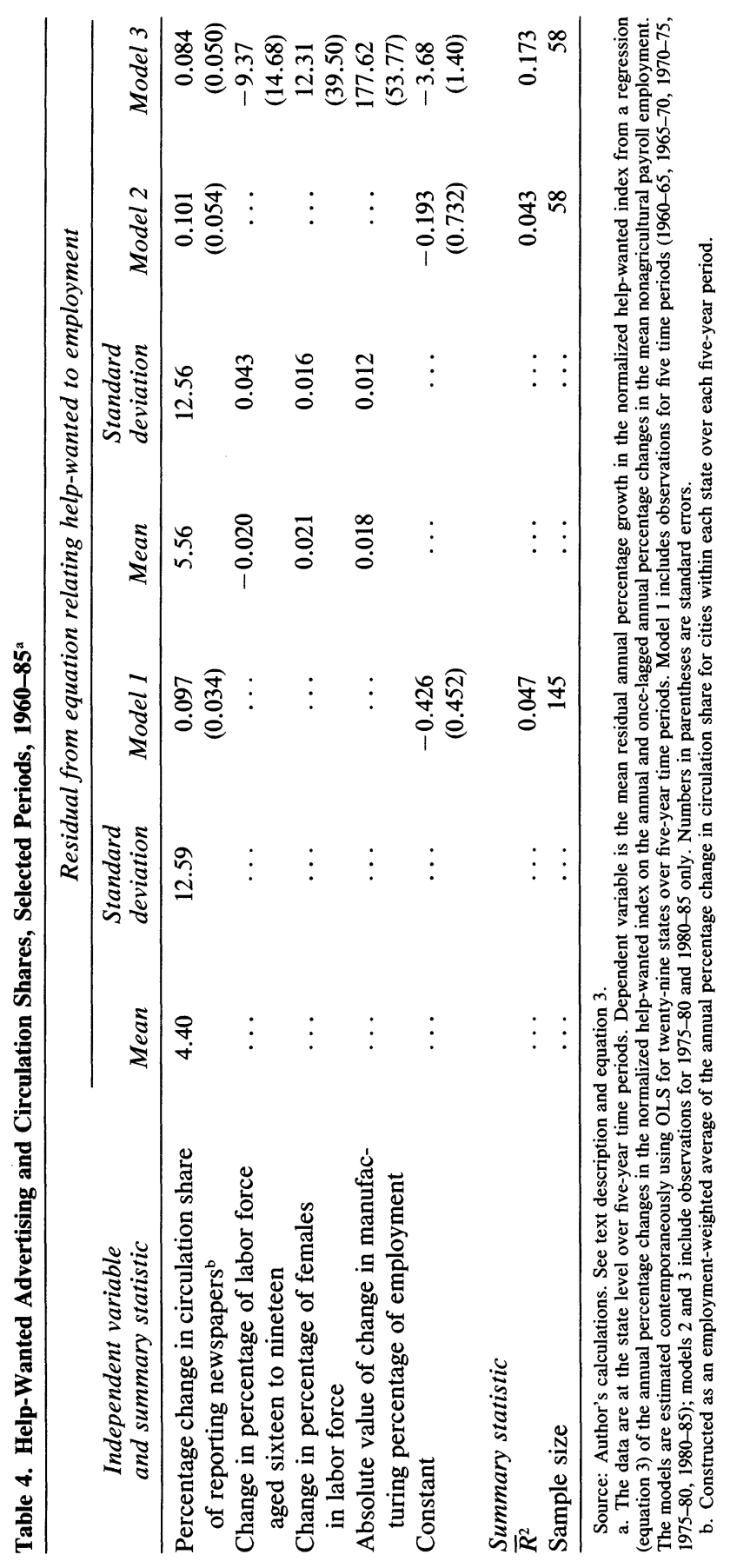


tent with this hypothesis. ${ }^{16}$ The addition of the just-mentioned control variables has only a small effect on the newspaper competition variable's coefficient. ${ }^{17}$

To what extent has declining newspaper competition raised the level of help-wanted advertising relative to the level of vacancies? To answer this question, I multiplied the weighted mean percentage growth in reporting newspapers' circulation shares over various periods by the estimated growth-in-circulation-share coefficient from the third model in table 4. If this coefficient accurately captures the effect of declining competition on the volume of help-wanted advertising in survivor papers, declining newspaper competition has contributed substantially to the observed growth in the help-wanted index: 5.8 percent from 1960 to $1965,2.6$ percent from 1965 to $1970,1.8$ percent from 1970 to 1975 , 3.8 percent from 1975 to 1980 , and 3.9 percent from 1980 to 1985 . Declining newspaper competition may account for close to half of the drift in the help-wanted-unemployment relationship between 1960 and 1970 , though it does not appear to account for as large a fraction of the more pronounced shift after 1970 .

THE ADJUSTED HELP-WANTED-UNEMPLOYMENT RELATIONSHIP

To summarize, changes in the occupational composition of employment, changes in employers' advertising practices plausibly linked to EEO and affirmative action pressures, and declining newspaper competition have all affected the volume of help-wanted advertising. The cumulative effect of changes in occupational mix since 1960 has been quite small, but changes in employers' advertising practices may have added 10 percent during the 1970s, and declines in newspaper competition, 20 percent between 1960 and 1985 . Table 5 summarizes my estimates of the effect of each, and of the combined effect of all three, on the volume of help-wanted advertising during successive five-year periods.

The estimates summarized in table 5 can be manipulated to yield a

16. The effects of both demographics and changes in the sectoral composition of demand receive further attention later.

17. Weighted regressions, with each observation weighted by the sum of payroll employment in SMSAs with reporting newspapers in the state, yield results very similar to those reported in table 4 . 
Table 5. Adjustments to the Help-Wanted Index, Selected Periods, 1960-85

\begin{tabular}{|c|c|c|c|c|c|}
\hline Adjustment and index & $1960-65$ & $1965-70$ & $1970-75$ & $1975-80$ & $1980-85$ \\
\hline \multicolumn{6}{|l|}{$\begin{array}{l}\text { Percentage drift in volume of help- } \\
\text { wanted advertising due to: }\end{array}$} \\
\hline $\begin{array}{l}\text { Changes in the occupational } \\
\text { composition of employment }\end{array}$ & 0.0 & 0.0 & 2.5 & 0.0 & 0.0 \\
\hline $\begin{array}{l}\text { Changes in employers' adver- } \\
\text { tising practices }\end{array}$ & 0.0 & 0.0 & 4.0 & 6.0 & 0.0 \\
\hline Declines in newspaper & & & & & \\
\hline competition & 5.8 & 2.6 & 1.8 & 3.8 & 3.9 \\
\hline $\begin{array}{l}\text { Total percentage drift in help- } \\
\text { wanted advertising }\end{array}$ & 5.8 & 2.6 & 8.5 & 10.0 & 3.9 \\
\hline $\begin{array}{l}\text { Mean unadjusted normalized help- } \\
\text { wanted index }\end{array}$ & 1.00 & 1.40 & 1.23 & 1.40 & 1.15 \\
\hline $\begin{array}{l}\text { Mean adjusted normalized help- } \\
\text { wanted index }\end{array}$ & 0.96 & 1.30 & 1.09 & 1.10 & 0.86 \\
\hline
\end{tabular}

Source: Author's calculations. See text. Figures are rounded.

rough-and-ready adjustment factor for the normalized help-wanted index. Changes in the occupational composition of employment were assumed to add half a percent a year to the volume of help-wanted advertising each year from 1970 through 1975. EEO and affirmative action pressures were assumed to add 2 percent a year between 1973 and 1978. The effects of the decline in newspaper competition were estimated for successive five-year periods; for the adjustment factor, I assumed that each period's effects were spread out evenly over the five years in the period.

The adjusted normalized help-wanted series for $1960-85$ is plotted against the civilian unemployment rate in figure $3 .{ }^{18}$ Though the shift is less pronounced than that in figure 1, there is still a significant increase in the help-wanted number associated with any given unemployment rate, and vice versa. A similar relationship exists between the weighted unemployment rate and the adjusted help-wanted series.

The time trend and post-1971 dummy variable coefficient estimates reported in table 6 summarize the magnitude of this shift. The numbers in the first model imply an increase of close to 30 percent in the adjusted help-wanted index associated with any given unemployment rate during

18. The unadjusted help-wanted series, my adjustment factors, and the adjusted helpwanted series are reported in the appendix. 
Figure 3. The Adjusted Normalized Help-Wanted Index and Unemployment, 1960-85 ${ }^{\text {a }}$

Adjusted normalized help-wanted index

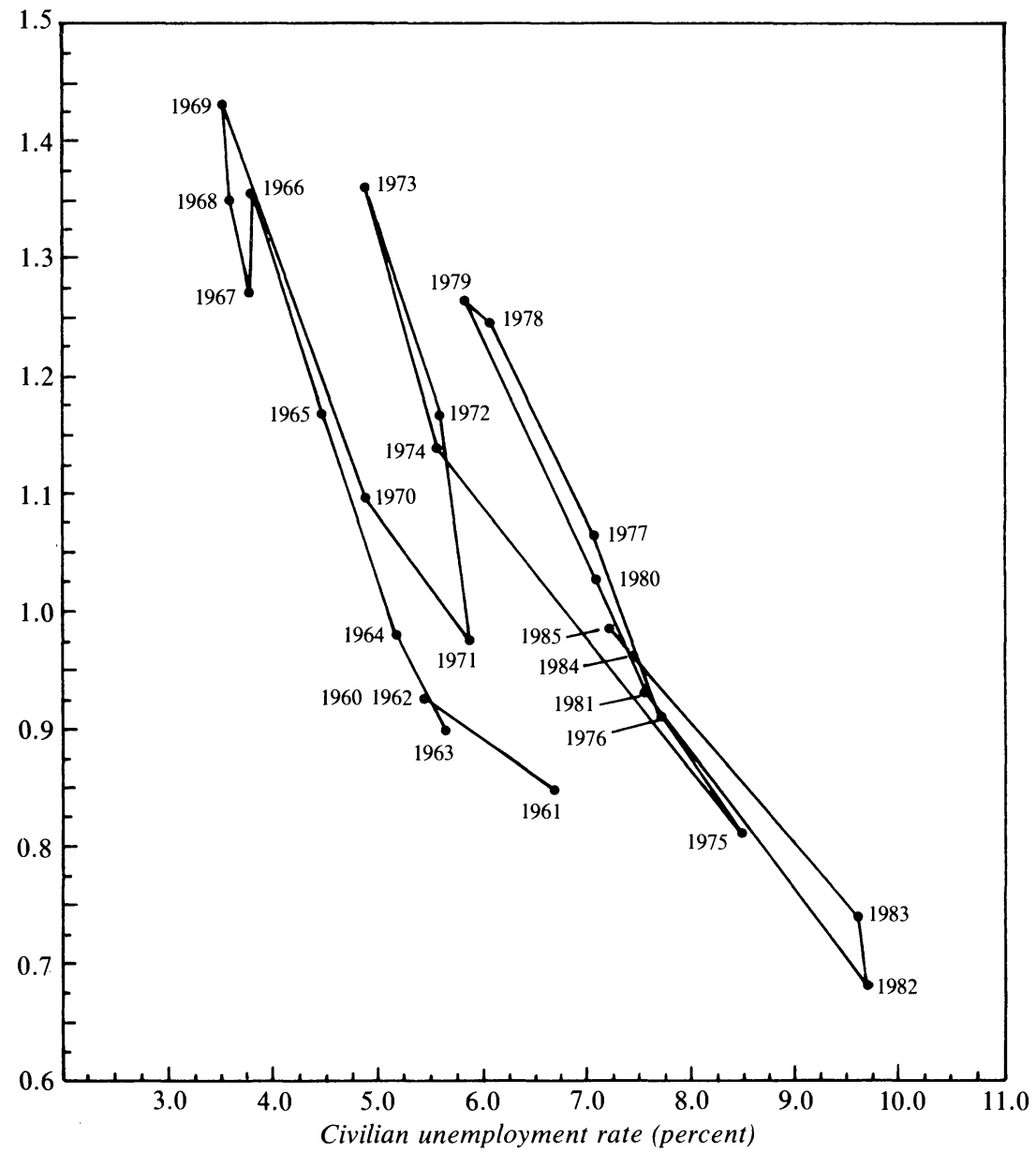

Sources: Adjusted normalized help-wanted index as calculated by the author. Unemployment data are from BLS, Handbook of Labor Statistics and Employment and Earnings.

a. The adjusted normalized help-wanted index equals the Conference Board help-wanted index divided by nonagricultural payroll employment in millions and adjusted for the sources of upward drift shown in table 5 and described in the text and in the appendix.

the post-1970 period. In the second model, which has a fixed-weight unemployment rate in place of the official unemployment rate, the shift is close to 20 percent. When we turn the relationship around, the estimates of the third model imply an increase of 1.9 percentage points in the civilian unemployment rate associated with any given adjusted 
Table 6. Adjusted Help-Wanted Advertising and Unemployment, 1960-85 ${ }^{\text {a }}$

\begin{tabular}{|c|c|c|c|c|c|c|}
\hline \multirow{3}{*}{$\begin{array}{l}\text { Independent variable } \\
\text { and summary statistic }\end{array}$} & \multirow[b]{3}{*}{ Mean } & \multirow{3}{*}{$\begin{array}{l}\text { Standard } \\
\text { deviation }\end{array}$} & \multicolumn{4}{|c|}{ Dependent variable } \\
\hline & & & \multicolumn{2}{|c|}{$\begin{array}{c}\text { Adjusted normal- } \\
\text { ized help-wanted } \\
\text { index } x^{\mathrm{b}}\end{array}$} & \multirow{2}{*}{$\begin{array}{c}\begin{array}{c}\text { Civilian } \\
\text { unemploy- } \\
\text { ment rate }\end{array} \\
\text { Model } 3\end{array}$} & \multirow{2}{*}{$\begin{array}{c}\begin{array}{c}\text { Fixed- } \\
\text { weight } \\
\text { unem- } \\
\text { ployment } \\
\text { ratec }\end{array} \\
\text { Model } 4\end{array}$} \\
\hline & & & Model 1 & Model 2 & & \\
\hline Time trend & 13.50 & 7.65 & $\begin{array}{c}0.006 \\
(0.003)\end{array}$ & $\begin{array}{c}0.004 \\
(0.002)\end{array}$ & $\begin{array}{c}0.048 \\
(0.014)\end{array}$ & $\begin{array}{r}0.039 \\
(0.013)\end{array}$ \\
\hline Post-1971 shift dummy & 0.54 & 0.51 & $\begin{array}{c}0.205 \\
(0.043)\end{array}$ & $\begin{array}{c}0.129 \\
(0.037)\end{array}$ & $\begin{array}{c}1.150 \\
(0.206)\end{array}$ & $\begin{array}{c}0.698 \\
(0.195)\end{array}$ \\
\hline Civilian unemployment rate & 6.10 & 1.70 & $\begin{array}{r}-0.271 \\
(0.042)\end{array}$ & $\ldots$ & $\cdots$ & $\cdots$ \\
\hline $\begin{array}{l}\text { (Civilian unemployment } \\
\text { rate) })^{2}\end{array}$ & 40.00 & 22.24 & $\begin{array}{c}0.009 \\
(0.003)\end{array}$ & $\cdots$ & $\cdots$ & $\ldots$ \\
\hline $\begin{array}{l}\text { Fixed-weight unemploy- } \\
\text { ment rate }\end{array}$ & 5.79 & 1.55 & $\cdots$ & $\begin{array}{r}-0.272 \\
(0.040)\end{array}$ & $\cdots$ & $\cdots$ \\
\hline $\begin{array}{l}\text { (Fixed-weight unemploy- } \\
\text { ment rate) })^{2}\end{array}$ & 35.84 & 19.17 & $\ldots$ & $\begin{array}{c}0.010 \\
(0.003)\end{array}$ & $\ldots$ & $\ldots$ \\
\hline $\begin{array}{l}\text { Adjusted normalized help- } \\
\text { wanted index }\end{array}$ & 1.06 & 0.20 & $\ldots$ & $\ldots$ & $\begin{array}{r}-17.040 \\
(2.687)\end{array}$ & $\begin{array}{r}-16.426 \\
(2.544)\end{array}$ \\
\hline $\begin{array}{l}\text { (Adjusted normalized help- } \\
\text { wanted index) }{ }^{2}\end{array}$ & 1.16 & 0.44 & . & $\ldots$ & $\begin{array}{c}5.160 \\
(1.244)\end{array}$ & $\begin{array}{c}4.787 \\
(1.178)\end{array}$ \\
\hline Constant & $\ldots$ & $\ldots$ & $\begin{array}{c}2.169 \\
(0.135)\end{array}$ & $\begin{array}{c}2.157 \\
(0.123)\end{array}$ & $\begin{array}{l}16.883 \\
(1.436)\end{array}$ & $\begin{array}{l}16.714 \\
(1.360)\end{array}$ \\
\hline \multicolumn{7}{|l|}{ Summary statistic } \\
\hline$\frac{\text { Durbin-Watson }}{\bar{R}^{2}}$ & $\cdots$ & $\cdots$ & $\begin{array}{l}1.93 \\
0.943\end{array}$ & $\begin{array}{l}1.87 \\
0.954\end{array}$ & $\begin{array}{l}1.57 \\
0.977\end{array}$ & $\begin{array}{l}1.55 \\
0.975\end{array}$ \\
\hline$R^{2}$ & $\cdots$ & $\cdots$ & 0.943 & 0.954 & 0.977 & 0.975 \\
\hline
\end{tabular}

Source: Author's calculations with data from the Conference Board and Employment and Earnings.

a. Annual data. All models were fit using OLS. Numbers in parentheses are standard errors.

b. Equals the Conference Board help-wanted index divided by nonagricultural payroll employment in millions and adjusted for the sources of upward drift shown in table 5 and described in the text. A listing of the index and total adjustment is also shown in the appendix.

c. Constructed by weighting the unemployment rates for each of sixteen age-sex groups by their 1965 labor force shares.

help-wanted index since 1970; estimates of the fourth model imply an increase of 1.3 percentage points in the demographically weighted unemployment rate associated with any given adjusted help-wanted index over the same period. ${ }^{19}$ Given the unavoidably crude nature of the adjustments made to the help-wanted series, it would be a mistake to make too much of the allocation of this shift between a smooth shift and a discrete jump. Nonetheless, there does seem to have been a significant movement in the vacancy-unemployment relationship during the 1970s.

19. The table 6 equations are not structural models, but rather offer a method of summarizing patterns in the data. In these models, the post-1971 shift dummy yielded better fits than dummy shift variables with other starting dates. 


\section{Why Has the Vacancy-Unemployment Relationship Shifted?}

The next question is why this shift occurred. Theory offers a number of possible explanations. ${ }^{20}$ The available evidence suggests that increased dispersion in regional economic conditions played an important, though not an exclusive, role. ${ }^{21}$

\section{A SIMPLE MATCHING MODEL}

The following simple model highlights the basic structure of the relationship between vacancies and unemployment in a particular labor market and thus serves as a useful prelude to discussion of the various causes of an outward shift of the vacancy-unemployment locus. Assume that the size of the labor force is fixed at $L$ and labor demand, $J$, is given exogenously. By definition

$$
E=J-V=L-U,
$$

where $E$ equals number employed, $V$ equals the number of vacant positions that employers would like to fill, and $U$ equals the number unemployed. In steady-state equilibrium, employment, vacancies, and unemployment must be such that flows into and out of employment are equal. Let the probability that any given job vacancy is filled during a particular time period depend upon the ratio of the number of vacancies to the number unemployed:

$$
p=p(V / U), p_{V}<0, p_{U}>0, p_{V V}>0, p_{U U}<0, \text { and } p_{V U}<0,
$$

20. Previous analyses of the microeconomic underpinnings of the vacancy-unemployment relationship include the papers in Edmund S. Phelps and others, Microeconomic Foundations of Employment and Inflation Theory (W. W. Norton, 1970); Jackman, Layard, and Pissarides, "On Vacancies"; Roger J. Bowden, "On the Existence and Secular Stability of the u-v Loci," Economica, vol. 47 (February 1980), pp. 35-50; and Christopher A. Pissarides, "Short-Run Equilibrium Dynamics of Unemployment, Vacancies and Real Wages," American Economic Review, vol. 75 (September 1985), pp. 67690.

21. Other recent discussions of the outward shift in the U.S. Beveridge curve include Medoff, "U.S. Labor Markets"; Martin Neil Baily, "The Problem of Unemployment in the United States,' 'in Jobs for the Future: Strategies in a New Framework (Washington, D.C.: Center for National Policy, May 1984), pp. 11-29; and Lawrence H. Summers, "Why Is the Unemployment Rate So Very High near Full Employment?' BPEA, 2:1986, pp. 339-83. 
where $p$ is the probability that a randomly selected job vacancy is filled, and $V$ and $U$ are as above. To keep things simple, I assume that a constant proportion, $s$, of employed workers leave theirjobs each period. Given $p$ and $s$, in steady-state equilibrium:

$$
p(V / U) V-s E=0,
$$

or, dividing through by employment and rearranging terms:

$$
p(v / u) v=s,
$$

where $v=V / E$ is the vacancy rate and $u=U / E$ is the unemployment rate.

Along the set of points satisfying equation 7 ,

$$
\frac{d v}{d u}=-\frac{p_{u}}{p+p_{v} v} .
$$

The steady-state locus is negatively sloped so long as changes in the vacancy rate produce less-than-proportional changes in $p$. Moreover, so long as changes in the vacancy rate produce less-than-proportional changes both in $p$ and in $p_{u}$, it is convex to the origin. Exactly where along its vacancy-unemployment locus a given labor market settles will depend upon the ratio of desired employment $(J)$ to the size of the labor force $(L)$. All else the same, an increase in desired employment raises the equilibrium vacancy rate and lowers the equilibrium unemployment rate; a decrease in desired employment has the opposite effects.

The simple model just sketched out captures, in a stylized way, the processes that determine vacancies and unemployment in a particular labor market. In an economy composed of many more or less separate labor markets defined along geographic or industrial lines, the aggregate relationship between vacancies and unemployment may be affected both by changes in the positions of the vacancy-unemployment locuses in specific labor markets and by changes in the distribution of labor demand across labor markets. I consider these alternative possibilities in turn.

\section{DEMOGRAPHIC AND BEHAVIORAL EXPLANATIONS}

Changes in search behavior on either side of the labor market can have an important effect on the position of the vacancy-unemployment locus. An easy way to think about such changes is to view reduced 
search intensity or increased choosiness on the part of either workers or employers as equivalent to a reduction in effective unemployment or effective vacancies. Define the effective unemployment rate as:

$$
u^{*}=c_{1} u,
$$

and the effective vacancy rate as:

$$
v^{*}=c_{2} v,
$$

where $c_{1}$ and $c_{2}$ are parameters that can change over time. If, for example, the typical unemployed person now contacts fewer prospective employers or holds out for a wage at a higher percentile in the overall wage distribution than he or she did fifteen years ago, $c_{1}$ would be smaller today than in the earlier period. Similarly, if employers have become more selective in hiring, $c_{2}$ would be smaller. If $c_{1}$ and $c_{2}$ can vary, equation 7 should be rewritten in terms of effective vacancies and effective unemployment:

$$
p\left(v^{*} / u^{*}\right) v^{*}=s,
$$

or, substituting from equations 9 and 10 :

$$
p\left(c_{2} v / c_{1} u\right) c_{2} v=s .
$$

Changes in search behavior that reduce $c_{1}$ clearly move the relationship between vacancies and unemployment outwards; so long as changes in effective vacancies have a less-than-proportional effect on $p$, changes in search behavior that reduce $c_{2}$ also shift the vacancy-unemployment locus outwards.

Exogenous increases in the turnover rate, $s$, are another possible source of increases in equilibrium vacancies and equilibrium unemployment.

Faster labor market growth could also shift outward the position of the vacancy-unemployment locus in a particular labor market. If both $L$ and $J$ are growing at $g$ percent a year, the vacancy rate and the unemployment rate cannot remain constant unless employment also grows at $g$ percent a year. This means that, in steady-state equilibrium, with possible changes in search behavior being ignored:

$$
p(V / U) V-s E=g E .
$$


Dividing through by employment and rearranging terms yields

$$
p(v / u) v=s+g .
$$

It is easy to see that increases in $g$ move the equilibrium vacancy rateunemployment rate locus away from the origin.

More rapid growth may also have an indirect effect on the position of the vacancy-unemployment locus. In a rapidly growing labor market, a relatively large fraction of the labor force are new to their jobs. Insofar as new employees are more likely to quit, or be discharged, rapid growth thus raises the turnover rate. Any secondary effect of more rapid growth on turnover will reinforce the outward shift in the vacancy-unemployment locus due directly to faster growth..$^{22}$

Changes in the demographic composition of the labor force are a potentially important source of change both in unemployed workers' search behavior and in the turnover rate. If youth or women differ from adult men primarily in the intensity with which they seek work while unemployed, the effects of changes in the demographic composition of the labor force on the vacancy-unemployment locus should largely be netted out by the substitution of a fixed-weight unemployment rate for the official unemployment rate in estimation of the vacancy-unemployment relationship. The findings in the earlier part of the paper do indicate that the vacancy-unemployment locus defined using a fixed-weight unemployment rate has been more stable than that defined using the official unemployment rate, though that locus has also shifted substantially.

Increases in the quit rate caused by the increased representation of young people and women in the labor force could raise both vacancies and unemployment. The use of a fixed-weight unemployment rate would not fully capture these effects. There is evidence that young workers have higher quit rates than do older workers. However, the baby boom's effect on the proportion of young workers in the labor force has already begun to recede. The proportion of the labor force aged sixteen to nineteen has fallen from its 1974 peak of 9.6 percent to 6.8 percent in 1985 , and the proportion of the labor force aged sixteen to twenty-four has fallen from 24.5 percent in 1978 to 20.5 percent in 1985 . If young

22. See James L. Medoff, "U.S. Labor Markets: Imbalance, Wage Growth, and Productivity in the 1970s," BPEA, $1: 1983$, pp. 87-120. 
workers' higher quit rates were responsible for the outward shift in the vacancy-unemployment relationship, it should have moved back toward the origin as the proportion of young workers in the labor force declined. This does not appear to have happened. Available evidence indicates that male-female quit rate differences are much smaller than those between younger and older workers, particularly when comparisons are made between men and women in comparable positions. ${ }^{23}$

Some have argued that, even beyond the effects of changes in labor force composition, today's unemployed workers search less intensely than did unemployed workers ten or fifteen years ago. ${ }^{24}$ While this view cannot easily be either proven or disproven, I know of no hard evidence in its favor. The major social program that might have affected unemployed workers' willingness to hold out for better jobs is the unemployment insurance (UI) program. As Gary Burtless has documented elsewhere, the UI replacement rate has shown little, if any, upward trend since World War II, and there has been no upward trend in the fraction of the unemployed receiving jobless benefits. Indeed, the proportion of the unemployed collecting jobless pay has fallen markedly in recent years; whereas 78 percent of the unemployed received jobless benefits in 1975 , only about 45 percent received benefits during $1982 .{ }^{25}$

Changes in family composition could also affect the search behavior of the unemployed, but there seem to have been offsetting trends at work here. For example, while the proportion of unemployed married men with at least one other family member employed rose from 39 percent in 1958 to 57 percent in 1981, the proportion of unemployed men who are married fell from 68 percent to 41 percent.

A point often overlooked in discussions of increasing unemployment,

23. See Jacob Mincer and Boyan Jovanovic, "Labor Mobility and Wages," in Sherwin Rosen, ed., Studies in Labor Markets (University of Chicago Press, 1981), pp. 21-63, for evidence on the effects of experience on quit rates, and Paula England, "Socioeconomic Explanations of Job Segregation," in Helen Remick, ed., Comparable Worth and Wage Discrimination: Technical Possibilities and Political Realities (Temple University Press, 1984), pp. 37-38, for a survey of studies on turnover rates by sex.

24. Jackman, Layard, and Pissarides, "On Vacancies," advance this explanation for the observed outward shift in the vacancy-unemployment relationship in the United Kingdom.

25. See Gary Burtless, "Unemployment Insurance and Labor Supply: A Survey" (Brookings, August 1986); and Burtless, "Why Is Insured Unemployment So Low?" BPEA, 1:1983, pp. 225-49. 
and in particular of outward shifts in vacancy-unemployment relationships, is that changes in employers' job-filling strategies are as plausible a contributing factor as changes in the intensity with which the unemployed seek work. In the United States, employers' efforts to actively recruit women and minorities have probably led to more extensive searches before positions are filled; all else the same, both vacancies and unemployment should have risen. Equal employment opportunity legislation has also probably raised the expected cost to employers of terminating employment relationships that prove to be unsatisfactory, since in many situations an employer who fires an employee is vulnerable to a lawsuit. This, too, could have led employers to be more selective in the initial hiring decision. Unfortunately, there is no obvious way to quantify the effects of changes in the legal environment on employers' recruiting behavior, and thence on vacancies and unemployment.

Rapid labor market growth had considerable appeal as an explanation for the outward shift in the vacancy-unemployment relationship through the end of the 1970s, but the experience since that time raises some questions. Between 1960 and 1970, the mean annual rate of growth in the labor force was 1.7 percent; that figure rose to 2.6 percent between 1970 and 1980. But the annual rate of growth in the labor force peaked in 1978 at 3.2 percent, and since 1980 labor force growth has been slower than it was during the 1960 s, averaging only 1.5 percent a year. Employment growth rate estimates based on household survey data have generally moved together with labor force growth rates; they averaged 1.8 percent during the $1960 \mathrm{~s}, 2.3$ percent during the $1970 \mathrm{~s}$, and 1.5 percent from 1980 to 1985 . Nonagricultural payroll employment growth was in fact most rapid during the 1960s (averaging 2.5 percent a year), somewhat slower during the 1970s (2.1 percent), and slowest during the first half of the 1980 s (1.5 percent). ${ }^{26}$ If the rate of labor force growth were the only factor affecting the vacancy-unemployment locus, it should have begun to shift inward in the late 1970s or early 1980s. But if my adjusted help-wanted series is a valid proxy for movements in vacancies, that shift did not occur.

26. The large difference between the household survey employment growth and payroll survey employment growth during the 1960s is accounted for by the fact that agricultural employment, private household employment, and self-employment all fell during the 1960s. 


\section{SECTORAL DISPERSION EXPLANATIONS}

For sectoral dispersion explanations about the outward shift in the aggregate vacancy-unemployment locus to have any appeal, the average outward shift in individual sectors' vacancy-unemployment curves must be smaller than the shift in the aggregate curve. To assess the outward shift in individual states' help-wanted-unemployment curves for each of the twenty-nine states for which help-wanted data are available, I first adjusted the help-wanted series to take account of sources of upward drift in the same fashion as described for the aggregate help-wanted index. Unemployment rates based on the Current Population Survey are available for twenty-four of these twenty-nine states from 1970 on; these states receive 91 percent of the total weight in the computation of the aggregate help-wanted index. For each of these twenty-four states, I fit the following regression using 1970 through 1985 data:

$$
A D J N H W I_{i t}=\beta_{0}+\beta_{1} U R_{i t}+\beta_{2} U R_{i t}^{2}+\beta_{3} T I M E+\beta_{4} D 72+\epsilon,
$$

where $A D J N H W I$ is the adjusted normalized help-wanted index, $U R$ is the unemployment rate, TIME is an annual time trend that equals 1 in $1970, D 72$ is a dummy variable that equals 1 in 1972 and later years, $i$ indexes states, and $t$ indexes time periods. Using the estimated $\beta_{3}$ 's and $\beta_{4}$ 's, I computed the implied percentage shift in the adjusted volume of help-wanted advertising associated with given unemployment in each state, and then took the weighted average of these estimates using the same payroll employment weights that are used in the computation of the aggregate help-wanted index. Finally, I compared this weighted average to the shift in the national adjusted help-wanted-unemployment relationship based on the same model estimated using data for 1970 to 1985.

On average, the adjusted state help-wanted index associated with any given unemployment rate drifted upwards only 12 percent from 1970 to 1985, while the national adjusted index drifted up 27 percent. With the position of the adjusted help-wanted index and the unemployment rate in the procedures just described reversed, the state unemployment rate associated with any given adjusted volume of help-wanted advertising rose 0.4 percentage point, on average, between 1970 and 1985; the comparably estimated increase in the national unemployment rate was 
1.8 percentage points. ${ }^{27}$ The weighted average shift in the adjusted helpwanted-unemployment curves for the individual states for which data are available is less than half as large as the adjusted aggregate shift. Changes in the distribution of labor demand across states may thus have affected aggregate vacancies and unemployment.

The usual sectoral dispersion explanation rests on the nonlinearity of the equilibrium vacancy-unemployment locus. ${ }^{28}$ Assume that all sectors share the vacancy-unemployment relationship shown in the left-hand panel of figure 4 . If all sectors are at point $A$, the aggregate vacancy rate and the aggregate unemployment rate equal the rates in the individual sectors, $v_{0}$ and $u_{0}$. Now suppose that labor demand increases in some sectors while decreasing by an offsetting amount elsewhere. If labor is immobile between sectors and there are no further shocks to the system, the sectors where labor demand has increased will move to a new equilibrium with higher vacancies and lower unemployment, say at point $B$, while the sectors where labor demand has fallen will move to a new equilibrium with lower vacancies and higher unemployment, say at point $C$. Total labor demand has not changed, but because of the convexity of the vacancy-unemployment relationship within each sector, the increased dispersion of labor demand across sectors raises the aggregate vacancy rate from $v_{0}$ to $v_{1}$ and the aggregate unemployment rate from $u_{0}$ to $u_{1}$. Any increase in the dispersion of demand across sectors with relatively impermeable boundaries-whether defined along geographic, industrial, or other lines-could increase the aggregate unemployment rate. ${ }^{29}$

The preceding explanation rests heavily on the convexity of the equilibrium vacancy-unemployment relationship. But increased dispersion of desired employment growth rates could be important even if this

27. The national numbers here do not agree precisely with those in the first part of the paper, since they are based on models fit using data for 1970 through 1985, rather than on models fit using data for 1960 through 1985 . They are, however, very close.

28. The importance of dispersion in local demand conditions in a somewhat different context was emphasized by Richard G. Lipsey, "The Relation between Unemployment and the Rate of Change of Money Wage Rates in the United Kingdom, 1862-1957: A Further Analysis," Economica, vol. 27 (February 1960), pp. 1-31. See also Robert M. Solow, The Nature and Sources of Unemployment in the United States (Stockholm: Almquist and Wiksell, 1964).

29. All of this assumes that the position of the vacancy-unemployment locus is similar across sectors. Without actual data on vacancy rates, the assumption cannot be tested. 


$$
\begin{aligned}
& * 1 \\
& |A| A
\end{aligned}
$$


relationship were not convex. When labor demand in a sector increases, vacancies can increase instantaneously, but unemployment falls only with a lag as the newly available jobs are filled. When labor demand falls, some firms may be able to adjust simply by canceling vacancies, but others will have to let workers go to reach their new desired employment levels. On average, if labor demand rises in some sectors and falls by an offsetting amount in others, both vacancies and unemployment will rise, as shown in the right-hand panel of figure 4 . There the sector in which demand increases moves initially from $A$ to $B$ while the sector in which demand falls moves from $A$ to $C$. The average moves out from $A$ to $D$, the point midway between $B$ and $C$.

Things become more complicated if there are repeated shocks to desired employment; moreover, the asymmetry between sectors with above-average growth and those with below-average growth is likely to be less pronounced when the mean growth rate is positive, rather than zero as assumed in my simple example. How the economy ultimately adjusts to sector-specific shocks to labor demand will also depend upon whether the barriers between sectors are permeable or impermeable. Still, so long as positive labor demand shocks do not lead to immediate reductions in unemployment and as long as negative labor demand shocks are accommodated partly by canceling vacancies and partly by reducing employment, increased dispersion in employment growth rates should produce increases in both vacancies and unemployment. ${ }^{30}$

Dispersion in Levels. For increased dispersion in the level of labor market tightness to have been an important cause of the outward shift in the help-wanted-unemployment relationship, two things must be true. First, the dispersion of labor market tightness, as measured by either the dispersion in vacancy rates or the dispersion in unemployment rates, must have risen. Second, there must be significant curvature in the vacancy-unemployment locus.

Data on vacancy rates by state do not exist and the various state helpwanted indexes are not directly comparable, but data on unemployment are available by state. As shown in the first column of table 7 , the

30. The argument that increased dispersion in desired employment growth rates across sectors should raise both vacancies and unemployment underlies the argument concerning cyclical fluctuations in unemployment in Katharine G. Abraham and Lawrence F. Katz, "Cyclical Unemployment: Sectoral Shifts or Aggregate Disturbances?'” Journal of Political Economy, vol. 94 (June 1986), pp. 507-22. 
Table 7. Dispersion of Unemployment Rates and Employment Growth Rates, across States and across Industries, $1960-85^{\mathrm{a}}$

\begin{tabular}{|c|c|c|c|c|c|}
\hline \multirow[b]{3}{*}{ Year } & \multicolumn{3}{|c|}{ State dispersion measures } & \multirow{2}{*}{\multicolumn{2}{|c|}{$\begin{array}{c}\text { Industry dispersion } \\
\text { measures }\end{array}$}} \\
\hline & \multicolumn{2}{|c|}{ Unemployment rates ${ }^{\mathrm{b}}$} & \multirow[b]{2}{*}{$\begin{array}{l}\text { Employment } \\
\text { growth rates }\end{array}$} & & \\
\hline & $\begin{array}{c}\text { Old } \\
\text { method }\end{array}$ & $\begin{array}{l}\text { New } \\
\text { method }\end{array}$ & & $\begin{array}{l}\text { Unemploy- } \\
\text { ment rates }\end{array}$ & $\begin{array}{l}\text { Employment } \\
\text { growth rates }\end{array}$ \\
\hline 1960 & 1.25 & $\ldots$ & 1.17 & 2.70 & 1.39 \\
\hline 1961 & 1.48 & $\ldots$ & 1.82 & 3.30 & 2.77 \\
\hline 1962 & 1.15 & $\ldots$ & 1.28 & 2.74 & 1.20 \\
\hline 1963 & 1.02 & $\ldots$ & 1.52 & 2.67 & 0.97 \\
\hline 1964 & 0.91 & $\ldots$ & 1.11 & 2.25 & 0.95 \\
\hline 1965 & 0.93 & $\ldots$ & 1.20 & 2.03 & 1.10 \\
\hline 1966 & 0.82 & $\ldots$ & 1.72 & 1.60 & 2.16 \\
\hline 1967 & 0.80 & $\ldots$ & 1.38 & 1.42 & 1.85 \\
\hline 1968 & 0.74 & $\ldots$ & 1.30 & 1.33 & 0.95 \\
\hline 1969 & 0.75 & $\cdots$ & 1.34 & 1.16 & 1.05 \\
\hline 1970 & 1.20 & $\ldots$ & 1.91 & 2.01 & 2.85 \\
\hline 1971 & 1.51 & $\ldots$ & 2.00 & 2.19 & 2.71 \\
\hline 1972 & 1.38 & $\ldots$ & 2.39 & 2.00 & 1.74 \\
\hline 1973 & 1.22 & 1.27 & 1.95 & 1.76 & 2.00 \\
\hline 1974 & 1.44 & 1.27 & 1.73 & 2.13 & 1.48 \\
\hline 1975 & $\ldots$ & 1.89 & 2.47 & 3.87 & 5.25 \\
\hline 1976 & $\ldots$ & 1.77 & 1.71 & 2.85 & 1.61 \\
\hline 1977 & $\ldots$ & 1.45 & 1.63 & 2.33 & 1.63 \\
\hline 1978 & $\ldots$ & 1.15 & 1.80 & 1.92 & 1.99 \\
\hline 1979 & $\ldots$ & 1.13 & 1.73 & 1.86 & 1.49 \\
\hline 1980 & $\ldots$ & 1.57 & 2.56 & 2.76 & 2.93 \\
\hline 1981 & $\ldots$ & 1.73 & 2.17 & 2.79 & 2.11 \\
\hline 1982 & $\ldots$ & 2.16 & 1.87 & 4.18 & 3.64 \\
\hline 1983 & $\ldots$ & 2.17 & 1.77 & 3.69 & 2.69 \\
\hline 1984 & $\ldots$ & 1.82 & 1.45 & 2.52 & 2.34 \\
\hline 1985 & $\ldots$ & 1.63 & 1.43 & 2.48 & 2.05 \\
\hline
\end{tabular}

Source: Author's calculations with data from the Bureau of Labor Statistics. State unemployment rate data for 1974 and earlier years are from Employment and Training Report of the President, various issues.

a. All reported dispersions equal the square root of

$$
\sum_{i=1}^{K} \frac{\mathrm{E}_{i t}}{\mathrm{E}_{t}}\left(x_{i t}-\bar{x}_{t}\right)^{2}
$$

where $E_{i}$ is sector $i$ employment, $E$ is total employment, $x_{i}$ is either the sector $i$ unemployment rate or the sector $i$ employment growth rate, and $\bar{x}$ is the overall average of the variable of interest. The industry estimates use a nineindustry disaggregation: construction; mining; durables; nondurables; transportation utilities; trade; finance, insurance, and real estate; services; and government.

b. Before 1973 , the only available state unemployment rate data were estimates computed using the Bureau of Labor Statistics' so-called "handbook" method. Estimates computed using the handbook method are also available for 1973 and 1974. From 1973 on, estimates computed using a revised methodology that incorporates handbook procedures and CPS controls have been available. At least in 1973 and 1974, the estimated dispersion in unemployment rates estimated using the old handbook procedure is similar to the estimation in unemployment rates estimated using the new procedure. See BLS, Handbook of Methods, Bulletin 2134-1 (Government Printing Office, December 1982), for a description of these data. 
dispersion in unemployment rates has been significantly higher since 1970 than during the decade of the 1960s. This increase in unemployment rate dispersion reflects in part the fact that labor markets were slacker during the 1970s and early 1980s than during the 1960s, but that is not the whole story. Even in a regression equation with the dispersion in unemployment rates on the left-hand side and either the official or a fixed-weight unemployment rate on the right, a post-1969 shift dummy variable takes on a significant positive coefficient. ${ }^{31}$

What about the degree of curvature in the vacancy-unemployment relationship? In the state-specific models specified in equation 15 , the coefficient on the unemployment-rate-squared term always has the expected positive sign, and is more than twice as large as its standard error in eleven of the twenty-four state models. To illustrate the potential effects of curvature in the individual states' curves on the aggregate help-wanted-unemployment relationship, I carried out some simple calculations. I used the coefficients from each of the state-specific equations just described to compute what the expected value of the national adjusted normalized help-wanted index would have been in 1978 if the relationship between this vacancy-rate proxy and unemployment had been the same in all fifty states, under two alternative assumptions about the distribution of unemployment. In each case, I first assumed that unemployment was distributed across states with a mean equal to the actual 1970-85 mean unemployment rate in the particular state for which the equation had been estimated, and a variance of 0.77 , the mean annual variance in state unemployment rates between 1965 and 1970. I then assumed that the variance rose to 3.67, the mean annual variance in state unemployment rates between 1980 and 1985 . On average, the expected national help-wanted indexes calculated assuming the larger unemployment variance across sectors were 4 percent higher than those calculated using the smaller variance. While this number should not be interpreted as a measure of the actual shift in the national vacancy rate-unemployment rate relationship due to increased dispersion in labor demand conditions across states, both because the estimated help-wanted-unemployment equations are not truly structural relationships and because a part of the increase in the

31. Baily, "The Problem of Unemployment in the United States," finds a similar post1970 increase in the dispersion of unemployment rates across twenty-nine SMSAs, even after controlling for cyclical conditions. 
dispersion of unemployment rates between the two periods arose from cyclical conditions rather than from structural developments, it does illustrate that increased dispersion in labor market tightness across states could be responsible for some piece of the outward shift in the vacancy rate-unemployment rate relationship.

Dispersion in Growth Rates. Could increased dispersion in desired employment growth rates have affected the aggregate vacancy-unemployment locus? The second column of table 7 reports the dispersion in the actual growth rate of employment across states, which I assume to be correlated with the dispersion in desired employment growth rates. Like the dispersion in unemployment rates in column 1, the dispersion in employment growth rates jumped sharply after about 1970, more sharply than one would have expected even given the rise in unemployment. Unlike the dispersion in unemployment rates, the dispersion in employment growth rates fell in 1984 and 1985 to close to its 1960-70 average. It remains to be seen whether 1984 and 1985 represent a temporary aberration from the pattern of the past fifteen years or mark the beginning of a new era. If the latter, insofar as dispersion in employment growth rates across states has indeed been responsible for the outward shift in the aggregate adjusted help-wanted-unemployment relationship, that curve should now begin to shift inwards.

While available data do not permit analyses of the relationship between help-wanted advertising and unemployment by industry like those just reported by state, it is possible to look at what has happened to the dispersion of unemployment rates and the dispersion in employment growth rates across industries over time. The dispersion in unemployment rates across nine major industry sectors is reported in the third column of table 7 . The mean dispersion in industry unemployment rates is higher after 1970 than before, but, unlike the post-1970 increase in the dispersion of state unemployment rates, once cyclical conditions have been taken into account, no statistically significant increase remains. The fourth column of table 7 reports the dispersion in industry employment growth rates. The dispersion drifts upwards toward the end of the 1970 s, but that too appears to be attributable to the cyclical conditions prevailing during that period. ${ }^{32}$

32. Again, my results are consistent with those reported by Baily, "The Problem of Unemployment in the United States." I do not consider whether changes in some 
In brief, the available evidence supports the tentative conclusion that increased dispersion in states' economic health, but not increased dispersion in industry economic conditions, has contributed to the outward shift in the vacancy-unemployment locus.

\section{Conclusion}

Considerable recent interest has been directed toward understanding the substantial increases in Western economies' unemployment rates during the 1970s and early 1980s. The central objective of most of these investigations has been to understand what determines the demand for labor. ${ }^{33}$ But the evidence just considered suggests that weak labor demand is not the whole explanation for the increase in U.S. unemployment over the past decade and a half.

The help-wanted index, after adjustment for some identifiable sources of drift, is a useful indicator of job vacancies. Comparing the adjusted help-wanted index with unemployment rates over time shows that vacant jobs and unemployed workers are now matched with one another less smoothly than they used to be, in the sense that the vacancy rate associated with any given unemployment rate is significantly higher than in the past. Careful studies of both the United Kingdom and West Germany indicate that there have also been significant outward shifts in those countries' vacancy-unemployment relationships, and casual inspection of available data suggests the same may be true in some of the other European countries as well. ${ }^{34}$

industries' employment could have different consequences than changes in the employment of others, an issue taken up by Summers, "Why Is the Unemployment Rate So Very High near Full Employment?"

33. Contributions to the literature on the subject include Michael Bruno and Jeffrey Sachs, The Economics of Worldwide Stagflation (Harvard University Press, 1985); C. R. Bean, P. R. G. Layard, and S. J. Nickell, "The Rise in Unemployment: A Multi-country Study," Economica, vol. 53 (Supplement 1986), pp. S1-S22, and other papers in the same issue; John McCallum, "Unemployment in OECD Countries in the 1980s,"' The Economic Journal, vol. 96 (December 1986), pp. 942-60; and Robert M. Coen and Bert G. Hickman, "Keynesian and Classical Unemployment in Four Countries,"' BPEA 1:1987, pp. 123-93.

34. See Jackman, Layard, and Pissarides, "On Vacancies," for evidence on the United Kingdom; and Wolfgang Franz, "Match or Mismatch? The Anatomy of Structural/ Frictional Unemployment in Germany: A Theoretical and Empirical Investigation" (University of Stuttgart, 1986), for evidence on West Germany. The OECD Main Economic Indicators data bank includes vacancy data for a number of countries. 
Why has the U.S. vacancy-unemployment relationship shifted? Changes in the demographic composition of the labor force are one, but not the only, factor. Greater selectiveness in employers' hiring policies could have played a role but is hard to quantify. An important piece of evidence is that the weighted average outward shift in individual states' adjusted help-wanted-unemployment curves is substantially less pronounced than the outward shift in the national adjusted help-wantedunemployment curve. This fact, combined with evidence that both the dispersion of unemployment rates and the dispersion of employment growth rates across states have been substantially larger since 1970 than before, suggests that increased regional disparities in economic conditions have contributed to the outward shift in the national vacancyunemployment relationship.

\section{APPENDIX}

\section{The Adjusted Help-Wanted Series}

THE NORMALIZED help-wanted index used at the start of the paper is reported in the first column of table A-1. As discussed at length in the text, changes in the occupational composition of employment, EEO and affirmative action pressures on employers, and declining newspaper competition all could have affected the volume of help-wanted advertising. The adjustment factor that I used to purge the normalized helpwanted index of these influences is reported in the second column of table A-1, and the resulting adjusted help-wanted series appears in the third column of the table. 
Table A-1. The Adjusted Normalized Help-Wanted Index, 1960-85

\begin{tabular}{|c|c|c|c|}
\hline Year & $\begin{array}{l}\text { Normalized help- } \\
\text { wanted index } \\
\text { (1) }\end{array}$ & $\begin{array}{c}\text { Normalized } \\
\text { help-wanted } \\
\text { adjustment factor } \\
(2)\end{array}$ & $\begin{array}{l}\text { Adjusted normalized } \\
\text { help-wanted index } \\
(3)=(1) \div(2)\end{array}$ \\
\hline 1960 & 0.9253 & 1.0000 & 0.9253 \\
\hline 1961 & 0.8569 & 1.0116 & 0.8471 \\
\hline 1962 & 0.9458 & 1.0232 & 0.9242 \\
\hline 1963 & 0.9300 & 1.0352 & 0.8984 \\
\hline 1964 & 1.0268 & 1.0472 & 0.9805 \\
\hline 1965 & 1.2394 & 1.0593 & 1.1700 \\
\hline 1966 & 1.4505 & 1.0648 & 1.3622 \\
\hline 1967 & 1.3562 & 1.0703 & 1.2672 \\
\hline 1968 & 1.4493 & 1.0758 & 1.3472 \\
\hline 1969 & 1.5481 & 1.0814 & 1.4317 \\
\hline 1970 & 1.1915 & 1.0869 & 1.0962 \\
\hline 1971 & 1.0659 & 1.0964 & 0.9722 \\
\hline 1972 & 1.2905 & 1.1058 & 1.1669 \\
\hline 1973 & 1.5165 & 1.1154 & 1.3596 \\
\hline 1974 & 1.3045 & 1.1476 & 1.1367 \\
\hline 1975 & 0.9565 & 1.1807 & 0.8102 \\
\hline 1976 & 1.1060 & 1.2135 & 0.9114 \\
\hline 1977 & 1.3262 & 1.2473 & 1.0633 \\
\hline 1978 & 1.5967 & 1.2821 & 1.2454 \\
\hline 1979 & 1.6409 & 1.2919 & 1.2702 \\
\hline 1980 & 1.3353 & 1.3019 & 1.0257 \\
\hline 1981 & 1.2202 & 1.3120 & 0.9300 \\
\hline 1982 & 0.8950 & 1.3223 & 0.6768 \\
\hline 1983 & 0.9903 & 1.3326 & 0.7431 \\
\hline 1984 & 1.2899 & 1.3430 & 0.9605 \\
\hline 1985 & 1.3326 & 1.3535 & 0.9846 \\
\hline
\end{tabular}

Source: Author's calculations with data from the Conference Board and Employment and Earnings.

a. The normalized help-wanted index equals the Conference Board index divided by nonagricultural payroll employment in millions. The normalized help-wanted adjustment factor equals

$$
\prod_{j=1}^{t} \prod_{i=1}^{3}\left(1+x_{i j}\right)
$$

where $x_{i j}$ is the proportional drift in the volume of help-wanted advertising due to factor $i$ in period $j$. The three sources of drift in help-wanted advertising (shown in table 5 and described in the text) accounted for are changes in the occupational composition of employment, changes in employers' advertising practices due to EEO and affirmative action pressures, and changes in the intensity of newspaper competition. 


\section{Comments and Discussion}

Michael Wachter: In this paper Katharine Abraham provides a very useful analysis of the help-wanted advertising series and its relationship with job vacancies and unemployment. The paper makes four basic points: that the Conference Board's help-wanted index does provide a proxy measure of job vacancies; that the available help-wanted series has to be adjusted for structural changes in the labor market and in the newspaper industry if it is to be useful as a measure of labor market pressure; that the job-vacancy-unemployment (hereafter JV-U) relationship has shifted over time so that there are more job vacancies at any given level of unemployment; and that the shift in that relationship has been caused by increased dispersion in regional labor demand.

In discussing this paper, it is useful to divide it into two reasonably discrete topics: the construction of an adjusted help-wanted index variable and the identification of factors that might have altered the relationship between job vacancies (as measured by the adjusted helpwanted index) and unemployment.

Abraham makes an important contribution to labor market issues involving job vacancies. The major innovation is in analyzing the Conference Board's help-wanted index and in adjusting it so that it can be used to track long-run trends in labor demand. The empirical tracking of the JV-U relationship is also of great interest, although I would quarrel with Abraham's characterization of the causes of the hypothesized shift in that relationship.

Abraham first plays the role of a detective, tracking down some traditional and some obscure data sources. She confirms that although the Conference Board index tracks job vacancies in the few cases where both series are available, the index must be adjusted for certain structural 
changes in the labor market and in the newspaper industry. The usual suspect in adjusting any labor market variable is the occupational composition of the labor market. The new suspects are employers' advertising practices and the number of newspapers in the cities surveyed by the Conference Board. Abraham finds surprisingly strong evidence that changes in employers' advertising practices and a decline in newspaper competition are critical factors causing the help-wanted index to drift higher, independent of underlying demand pressure in the labor market.

Abraham's adjustment to the Conference Board series is shown in the appendix to her paper. The adjustment factor grows throughout the 1960 to 1985 period. Declining newspaper competition is the critical factor in the 1960s and again in the 1980s; employers' advertising practices are the critical influence in the 1970s. On account of these adjustments, the index is deflated by 35 percent, a very major change indeed.

It is worth noting that an especially useful feature of the help-wanted advertisements variable is that it is based on geographical data. Industry unemployment data are difficult to use on a geographical basis and, although household unemployment data can be used to provide geographical information on unemployment, they have some weaknesses when used in this way.

I read the first part of the paper as showing that since large adjustments have to be made to the help-wanted index, the resulting series has to be used with caution. This is particularly true given the somewhat arbitrary adjustments that Abraham is forced to make given data limitations. Even relatively minor additional adjustments to the help-wanted index could have material implications for its statistical relationship to such other indicators of market tightness as the unemployment rate.

The second part of the paper relates the adjusted help-wanted index (as a proxy for job vacancies) to the unemployment rate. Abraham argues that the estimated JV-U relationship shifts outward over time, although the shift seems to have stopped in the early $1980 \mathrm{~s}$.

But is this perceived worsening of the JV-U relationship real? As already noted, the adjustments Abraham makes to the help-wanted series are, of necessity, somewhat arbitrary. What if she has missed important effects on the volume of help-wanted advertising associated with changes in the occupational distribution of employment at a finer 
level of disaggregation than the broad occupational categories listed in table 3? What if the typical employer's advertising practices have changed more than the practices of the disproportionately large and disproportionately manufacturing employers in the BNA sample? What if the true effects of changes in reporting newspapers' circulation shares are even one standard error larger than the point estimate in table 4 ? Given the nature of the data on which Abraham must base her adjustments to the help-wanted series, it is entirely possible that she has significantly understated the importance of extraneous influences on the volume of help-wanted advertising, and as a result significantly overstated the magnitude of the shift in the relationship between vacancies and unemployment.

The final task of the Abraham paper is to argue that changes in the dispersion of regional demand are the likely cause of the shift in the JV-U relationship. Obviously such a claim requires that there be a shift to explain.

Abraham's evidence that geographical dispersion in job vacancies explains the JV-U shift is based on two facts: that there is considerable dispersion in help-wanted indexes and that state JV-U curves have shifted little. In other words, local areas have moved either to the right or to the left along their respective local curves. Such movements along the local curves shift the national relationship.

First, a minor quibble. Although Abraham argues that these changes are geographical and not industry-based, that distinction should not be pushed too far. For example, the food-fuel supply shocks of the 1970 s may have caused a considerable portion of the geographical dispersion during the 1970s. These changes originate in industry shifts. The resulting effects appear to be stronger in the local data than they are in the industry data because of multiplier effects that activate regional while diluting industry shifts.

A more central point could be used to tie this explanation together with the uncertainty about the magnitude of the shift in the JV-U relationship. Geographical dispersion should not generate long-lasting shifts in the national JV-U relationship. Geographical mismatches, unlike skill mismatches, are probably easier for the private parties in the labor market to correct. Although empirical evidence on this point is not available, it is at least plausible that labor suppliers find it easier to move 
from one region of the country to another than to shift from one skill sector to another. (The same point is less true for labor demanders.)

The temporary nature of the geographical dispersion factor fits with the evidence on the shift in the JV-U relationship. In other words, it is possible that geographical factors are driving the shift, but the ability of the private parties to respond to these changes has muted any material shift in the relationship.

\section{General Discussion}

Christopher Sims was more impressed by how much of the outward shift in the help-wanted-unemployment relationship Abraham's adjustments accounted for than by how much was left over after those adjustments were made. The largest single adjustment, that for changes in newspaper competition, is based on a coefficient with a relatively large standard error attached to it; Sims suspected that if that coefficient had been assumed to be one standard deviation larger, there would have been little outward shift left to explain.

While agreeing with Sims that Abraham's adjusted help-wanted series was probably not statistically robust, William Nordhaus was impressed by the similar movements of the Minnesota normalized help-wanted index and the Minnesota vacancy rate. Nordhaus also remarked that he found the conceptual basis of the help-wanted series more appealing than the conceptual basis of employer-reported vacancy statistics, since employers must pay for help-wanted advertisements. On this second point, Nordhaus drew an analogy to European and U.S. patent data. European patent holders must pay a graduated annual license fee to keep their patents; in the United States, once it is awarded, a patent is good for seventeen years with no further fees required. The European patent data thus provide better information on the volume of useful innovative activity.

Robert Hall commented that the help-wanted index is not the only labor market indicator that has diverged from the unemployment rate in recent years. Indicators such as the manufacturing layoff rate and the insured unemployment rate have signaled greater labor market tightness than the official unemployment rate since 1970. Hall also urged Abraham 
to push harder on sorting out the relative contributions of divergences in regional conditions and other factors common across all states in explaining the outward shift in the adjusted help-wanted-unemployment relationship.

James Tobin questioned whether positions advertised in newspapers all represent genuine vacancies. He reported that some years ago, a reporter for Fortune magazine followed up on all the help-wanted advertisements appearing in one medium-sized county's newspaper. Many of the positions advertised required specific skills that few individuals would possess. The reporter found that most of the ads did not represent jobs relevant to the unemployed, whose applications overwhelmed the few openings that were.

Frank Schiff regretted that the Bureau of Labor Statistics has never collected vacancy statistics on an ongoing basis. Though the Conference Board's help-wanted data are useful for some purposes, they are not a substitute for vacancy data collected directly from employers that include industry and occupational detail. The pilot projects conducted by the BLS during 1979 and 1980 demonstrated that vacancy data collection is feasible. The BLS itself has argued that a full-scale vacancy data collection effort would be prohibitively expensive. But Schiff concluded that a less ambitious ongoing program, perhaps limited to a few states, could yield valuable information at much lower cost. 